злочинності, прийнятий резолюцією 55/25 Генеральної Асамблеї від 15 листопада 2000 p. URL: https://zakon.rada.gov.ua/laws/show/995_791

9. Андрушко А.В., Нестерова І.А. Злочинність у сфері туристичного бізнесу: кримінологічна характеристика та запобігання: монографія. Ужгород : ТОВ «IBA», 2016. 220 с.

УДК 343.9

DOI https://doi.org/10.32844/2618-1258.2019.5-1.38

БАРДАЧОВ В.В.

\title{
ЗЛОЧИНИ У СФЕРІ СЛУЖБОВОЇ ДІЯЛЬНОСТІ, ЯКІ ВЧИНЯЮТЬ ПРАЦІВНИКИ ПАТРУЛЬНОЇ ПОЛЦІЇ, ЯК ОБ'ЄКТ КРИМІНОЛОГІЧНОГО ДОСЛІДЖЕННЯ
}

У статті надано кримінально-правову характеристику злочинам у сфері службової діяльності, що вчиняють працівники патрульної поліції. Встановлено, що до службових та корупційних правопорушень належать діяння, за які передбачено кримінальну, адміністративну, цивільно-правову та дисциплінарну відповідальність та які розподілено на такі, що пов'язані з виконанням працівниками Національної поліції службових обов'язків (службові зловживання), використанням ними спеціального правового статусу для вчинення інших злочинів, а також, які учинено поза службою.

Злочини у сфері службової діяльності, що вчиняються працівниками патрульної поліції - це суспільно небезпечні протиправні діяння, передбачені розділом XVII Особливої частини закону про кримінальну відповідальність, що посягають на нормальну діяльність правоохоронних органів та вчиняються громадянами України, які склали Присягу поліцейського, проходять службу на відповідних посадах у патрульній поліції і яким присвоєно спеціальне звання поліції під час виконання ними службових обов'язків. Зазначені суспільно небезпечні діяння поділяються на ті, що пов'язані із загально-професійними аспектами діяльності (ст. 364, 365,367 КК України), ті, що пов'язані із набуттям або укриттям незаконної матеріальної вигоди (366-1, 368, 369, 369-2 КК України), та ті, що пов'язані із спеціальною діяльністю (ст. 366, 370 КК України). Залежно від категорії посади (служби, підрозділу) змінюється специфіка виконуваних службових функцій, а отже, і зміст службових повноважень та компетенції, якими працівники володіють відповідно до службового становища. Водночас використання службових повноважень і можливостей, що передбачені службовим становищем, крім того, буде зумовлювати не тільки різний характер злочину, але і тяжкість наслідків.

Злочини у сфері службової діяльності, що вчиняються працівниками патрульної поліції, $є$ сегментом корупційних правопорушень, учинених працівниками правоохоронних органів. Серед чинників, що сприяють поширенню таких діянь у поліції та їх латентності, головними варто визнати недостатньо чітку регламентацію службових повноважень груп кадрів і категорій персоналу, приховування слідів як самими правопорушниками, так і їх безпосередніми керівниками, а також зв'язок службових зловживань з іншими категоріями правопорушень, до яких можуть бути причетні потерпілі та інші зацікавлені особи. Забезпечення належного стану дисципліни та законності серед особового складу поліції грунтується на стратегії випередження, що полягає у проведенні комплексу заходів, спрямованих на виявлення, запобігання й припинення корупційних, злочинних та інших протиправних діянь у поліцейських колективах.

Ключові слова: кримінально-правова характеристика, кримінальне правопорушення, злочин, корупція, патрульна поліція.

(С БАРДАЧОВ В.В. - здобувач кафедри кримінально-правових дисциплін та судових експертиз (Донецький юридичний інститут Міністерства внутрішніх справ України) 
The article gives a criminal-law description of crimes in the sphere of official activity committed by police patrol officers. It has been established that acts of corruption and corruption include acts for which criminal, administrative, civil and disciplinary responsibility is provided, and is divided into those related to the performance of official duties (official abuse) by employees of the National Police legal status for committing other crimes as well as offenses.

Service offenses committed by patrol officers are socially dangerous unlawful acts provided for in Section XVII of the Special Part of the Law on Criminal Liability, which encroach on the normal activity of law enforcement agencies and are committed by the citizens of Ukraine who take the Oath of Police Response in the patrol police and who have been assigned a special police rank in the course of their duty. These socially dangerous acts are divided into those related to general professional aspects of activity (Articles 364, 365, 367 of the Criminal Code of Ukraine) and to those related to the acquisition or concealment of illegal material gain $(366-1,368,369,369-2$ of the Criminal Code of Ukraine); the third includes crimes related to special activity (Articles 366,370 of the Criminal Code of Ukraine). Depending on the category of position (service, department), the specificity of the performed official functions changes, and therefore, the content of official powers and competences that employees possess according to their official position. At the same time, the exercise of official powers and the possibilities provided for in office will, in addition, not only cause the different nature of the crime, but also the gravity of the consequences.

Offenses committed by police officers are a segment of corruption offenses committed by law enforcement officials. Among the factors contributing to the proliferation of such acts in the police and their latency, the main ones are the lack of clear regulation of the powers of the groups of personnel and categories of personnel, the concealment of traces by both the offenders themselves and their direct leaders, as well as the relationship of official abuse with other categories of abuse. offenses to which victims and other interested persons may be involved. Ensuring the proper state of discipline and lawfulness among police personnel is based on a proactive strategy, which is to undertake a set of measures aimed at detecting, preventing and stopping corruption, crime and other illegal activities in police teams. police.

Key words: criminal characteristics, criminal offense, crime, corruption, patrol

Вступ. Реалізацію державної політики у сфері національної безпеки, боротьби зі злочинністю та запобігання корупції покладено на правоохоронні органи, зокрема новостворену Національну поліцію України. Президент України та Уряд неодноразово наголошували на необхідності консолідації зусиль усіх гілок та інституцій влади, громадськості, освітян і науковців щодо реформування органів правопорядку, які мають стати не лише ефективним інструментом протидії криміналітету, а й забезпечувати безумовне дотримання законності, недопущення порушень прав і свобод громадян та службової дисципліни.

Водночас в органах поліції робота щодо запобігання правопорушенням серед особового складу не $\epsilon$ достатньо ефективною, контроль за службовою діяльністю підлеглих з боку керівників, передусім середньої та низової ланок, залишається здебільшого формальним, що призводить до учинення поліцейськими кримінальних правопорушень і корупційних діянь. За даними Генеральної прокуратури та Департаменту внутрішньої безпеки Національної поліції України, упродовж 2014-2018 рр. судами винесено обвинувальні вироки стосовно 254 колишніх міліціонерів та поліцейських, з яких $196(82,0 \%)$ засуджено за злочини у сфері службової діяльності, зокрема передбачені ст. 364, 365, 368 Кримінального кодексу (далі - КК) України $[1 ; 2 ; 3$, с. 10-11]. У багатьох випадках службовий статус працівників поліції полегшує (уможливлює) вчинення ними інших злочинів проти життя та здоров'я, волі, честі й гідності особи, власності, правосуддя, у сфері обігу наркотичних засобів, використання комп'ютерних мереж, безпеки руху, моральності тощо.

Постановка завдання. Метою статті $€$ аналіз та визначення специфіки злочинів у сфері службової діяльності, які вчиняють працівники патрульної поліції, як об'єкт кримінологічного дослідження. 
Результати дослідження. Незважаючи на системні перетворення, люстраційні та антикорупційні заходи, рівень злочинності серед працівників поліції залишається досить високим, хоча останніми роками його вдалося дещо стабілізувати. Факти зловживань, перевищення влади або посадових повноважень, одержання неправомірної вигоди та інші надзвичайні події негативно позначаються на іміджеві усієї правоохоронної системи, сприяють зростанню рівня недовіри громадян до здатності цих підрозділів забезпечити належний правопорядок у країні.

Чинний КК України містить розділ XVII «Злочини у сфері службової діяльності та професійної діяльності, пов'язаної з наданням публічних послуг», що встановлює кримінальну відповідальність за вчинення службовими особами злочинів. Злочини, які зазначені в цьому розділі, об'єднані законодавцем на підставі родового об'єкта, якими є суспільні відносини у сфері службової та професійної діяльності. Перед науковою громадськістю постає складне й неоднозначне завдання виваженого застосування заходів кримінально-правової репресії щодо службових правопорушень різних категорій управлінського персоналу [4, с. 849]. У КК України є норми, що перебувають за межами розділу XVII, але встановлюють кримінальну відповідальність за вчинення злочину службовими особами.

Службовим злочином вважається діяння (дія або бездіяльність) службової особи, пов'язане з використанням нею наданої їй влади або службового становища 3 порушенням нормальної діяльності державного апарату або апарату підприємств, установ чи організацій незалежно від форми власності, із заподіянням істотної шкоди правам, свободам та інтересам окремих громадян або державним чи громадським інтересам або інтересам юридичних осіб. Отже, службовий злочин може вчинити лише службова особа. Службовими особами у ст. 364, 368, 369 КК України є особи, які постійно, тимчасово чи за спеціальним повноваженням здійснюють функції представників влади чи місцевого самоврядування, а також обіймають постійно чи тимчасово в органах державної влади, органах місцевого самоврядування, на державних чи комунальних підприємствах, в установах чи організаціях посади, пов'язані з виконанням організаційно-розпорядчих чи адміністративно-господарських функцій, або виконують такі функції за спеціальним повноваженням, яким особа наділяється повноважним органом державної влади, органом місцевого самоврядування, центральним органом державного управління із спеціальним статусом, повноважним органом чи повноважною службовою особою підприємства, установи, організації, судом або законом (примітка 1 до ст. 364 КК України). Службовими особами також визнаються посадові особи іноземних держав (особи, які обіймають посади в законодавчому, виконавчому або судовому органі іноземної держави, у тому числі присяжні засідателі, інші особи, які здійснюють функції держави для іноземної держави, зокрема для державного органу або державного підприємства), а також іноземні третейські судді, особи, уповноважені вирішувати цивільні, комерційні або трудові спори в іноземних державах у порядку, альтернативному судовому, посадові особи міжнародних організацій (працівники міжнародної організації чи будь-які інші особи, уповноважені такою організацією діяти від ії імені), члени міжнародних парламентських асамблей, учасником яких є Україна, та судді і посадові особи міжнародних судів (примітка 2 до ст. 364 КК України) [5, с. 860-864].

Корупційними злочинами відповідно до КК України вважаються злочини, передбачені ст. $191,262,308,312,313,320,357,410$, у разі їх вчинення шляхом зловживання службовим становищем, а також злочини, передбачені ст. 210, 354, 364, 364-1, 365-2, 368-369-2 КК [6].

Визначення системи злочинів у сфері службової діяльності та професійної діяльності, пов'язаної з наданням публічних послуг, що можуть вчиняти працівники патрульної поліції, з використанням ними своїх службових повноважень, здійснення групування цих злочинів за певними критеріями, розроблення й надання науково обгрунтованих пропозицій щодо вдосконалення чинного КК України в частині кримінальної відповідальності працівників Національної поліції має важливе значення для здійснення правоохоронної функції держави [7, с. 225-228].

Слушною є позиція О. Мартиненка, який зазначає необхідність врахування того, що під злочинами, які вчиняють працівники органів внутрішніх справ, слід розуміти передбачені КК України усі суспільно небезпечні винні діяння, вчинені працівниками органів внутрішніх справ 3 використанням службового становища (у широкому розумінні) [8, с. 62], тому кримінально-правова класифікація злочинів, учинених працівниками поліції, може бути зведена до їхнього групування відповідно до розділів Особливої частини КК України. Критерії, покладені в основу кримінально-правової класифікації, безумовно, становлять інтерес для кримінології, але не в усьому забезпечують потреби кримінологічної теорії та практики, оскільки не можуть повною мірою охопити всі особливості злочинів, що мають значення для їх запобігання. Кримінологічна 
ж класифікація злочинів передбачає урахування тих чи інших критеріїв (ознак) залежно від цілей класифікації. Для кримінологічної класифікації набагато важливіше враховувати ознаки, що свідчать про характер антисуспільної спрямованості особистості винного, її глибину і стійкість, про механізм, спосіб злочинного зазіхання, обставини, що сприяють вчиненню злочину.

Стосовно класифікації злочинів, учинених працівниками поліції, за таким критерієм, як зв'язок злочинного діяння з виконанням працівником своїх службових функцій, на нашу думку, увесь масив досліджуваних нами злочинів можна поділити на дві групи: службові і загальнокримінальні злочини, вчинені з використанням службового становища. До групи службових належать усі злочини, вчинені працівниками поліції у зв'язку з виконанням ними своїх службових функцій. Тобто злочини, безпосередньо пов'язані з проходженням державної служби в підрозділах поліції і виконанням специфічних завдань, покладених на них законом, з метою регулювання правовідносин у сфері правопорядку. Характер злочинів цієї групи визначається насамперед службовою діяльністю працівника поліції, специфікою виконуваних ним функцій. До групи загальнокримінальних злочинів, учинених із використанням службового становища, належать злочини, що можуть бути вчинені в будь-якій сфері інтересів, які охороняються законом. До них належать загальнокримінальні злочини, вчинені працівниками поліції під час виконання ними своїх службових обов'язків або поза службою, але тим або іншим чином пов'язані з використанням працівником свого службового становища (у широкому розумінні) [7, с. 227].

О. Ігнатов зазначає, що доцільно класифікувати злочини, вчинені працівниками правоохоронних органів, також і за детермінуючими підставами, що виявляється через мотивацію та дії винного. Дотримуючись концепції, відповідно до якої рушійною силою деструктивної поведінки (детермінуючими підставами) є агресія, експансія та обман, що в реальному прояві виступають як окремо, так і в сполученні один з одним, варто за доцільне поділити весь масив злочинних посягань, що становлять цей вид злочинів, на три основні групи: 1) злочини, мотивація яких пов'язана 3 агресією (переважно злочини, що вчиняють працівники правоохоронного органу у сфері сімейно-побутових відносин); 2) злочини, мотивація яких пов'язана з експансією (переважно злочини, що вчиняють працівники правоохоронного органу поза сферою сімейно-побутових відносин та не пов'язані зі службовою діяльністю); 3) злочини, мотивація яких пов'язана 3 обманом (переважно злочини, що вчиняють працівники правоохоронного органу у зв'язку зі службовою діяльністю) [9, с. 98]. Також можливо класифікувати злочини, вчинені працівниками органів внутрішніх справ, відповідно до диференціації суб'єкта злочину (працівника правоохоронного органу), залежно від його приналежності до тієї чи іншої служби, підрозділу. Залежно від приналежності працівника до певної служби, підрозділу змінюється специфіка виконуваних службових функцій, а отже, і зміст службових повноважень та компетенції, якими працівники володіють відповідно до службового становища. Так, одні службові особи можуть вчинити певні злочини, інші - ні. Водночас використання службових повноважень і можливостей, що передбачені службовим становищем, крім того, буде зумовлювати не тільки різний характер злочину, але і тяжкість наслідків. За результатами проведеного дослідження встановлено, що кількість учинених злочинів, а отже, і притягнутих до кримінальної відповідальності працівників, залежить від категорії служби у поліції [10, с. 212].

Таким чином, злочини у сфері службової діяльності, що вчиняють працівники патрульної поліції Національної поліції України, можна поділити на групи: перша пов'язана із загальнопрофесійними аспектами діяльності (ст. 364, 365, 367 КК України); друга група пов'язана з набуттям або укриттям незаконної матеріальної вигоди (366-1, 368, 369, 369-2 КК України); до третьої належать злочини, що пов'язані з вузькоспеціальною діяльністю (ст. 366, 370 КК України).

За офіційними статистичними даними, зловживання владою або службовим становищем складає $63 \%$ усіх зареєстрованих кримінальних правопорушень, що вчиняються працівниками патрульної поліції $[1 ; 2 ; 3]$.

Об’єктивна сторона зловживання владою або службовим становищем (ч. 1 ст. 364 К України) має три обов'язкові ознаки: діяння - використання службовою особою влади чи службового становища всупереч інтересам служби, що полягає в певних діях або бездіяльності суб'єкта; наслідки, що виявляються в завданні істотної шкоди охоронюваним законом правам, свободам та інтересам окремих громадян або державним чи громадським інтересам, або інтересам юридичних осіб; причинний зв'язок між діянням і наслідками. Відсутність хоча б однієї із зазначених ознак свідчить про відсутність складу злочину, передбаченого ст. 364 КК України [5, с. 845].

Зловживання владою - це вчинення службовою особою, яка постійно або тимчасово здійснює функції представника влади, умисного діяння з використанням своїх повноважень, якими 
вона наділена на підставі законів та інших нормативно-правових актів, всупереч інтересам служби. Зловживання службовим становищем - це зазвичай використання службових повноважень, пов'язаних із здійсненням (реалізацією) повноважень, якими службова особа наділена займаною посадою, всупереч інтересам служби [5, с. 845].

Разом $з$ тим, як зазначає В.І. Борисов, зловживання службовим становищем матиме місце не лише під час вчинення службовою особою діяння в межах своєї компетенції, тобто діяння, пов'язаного з власними повноваженнями, але й у випадках, коли службова особа використала авторитет своєї посади, службові зв'язки, а також можливість давати вказівки», рекомендації підпорядкованим організаціям і через своє службове становище могла контролювати їх виконання тощо [11, с. 49].

Під використанням влади чи службового становища всупереч інтересам служби необхідно розуміти вчинення службовою особою таких порушень своїх службових обов'язків, які заподіюють істотну шкоду охоронюваним законом інтересам окремих громадян, державним, громадським інтересам або інтересам юридичних осіб [11, с. 50].

Поняття «інтереси служби» безпосередньо пов'язане з обсягом прав та обов’ язків службової особи підприємства, установи чи організації, тобто іії повноваженнями (компетенцією). Відповідно до ч. 1 ст. 1 Закону України «Про державну службу» [12] державна служба - це публічна, професійна, політично неупереджена діяльність із практичного виконання завдань і функцій держави. Такі особи є державними службовцями. У контексті п. 1 примітки до ст. 364 під інтересами служби необхідно розуміти як законні інтереси конкретного підприємства, установи, організації незалежно від форми власності, якому (якій) «служить» службова особа. Обов'язковим є встановлення того, яким саме законним інтересам (зокрема, інтересам окремих громадян, інтересам держави чи інтересам підприємства) заподіяна шкода діянням службової особи і яка саме (матеріальна, нематеріальна), їі розмір, а також заподіяння якої шкоди іншим інтересам відвернено діянням службової особи. Питання про співвідношення інтересів держави, суспільства в цілому і окремого підприємства, установи чи організації незалежно від форми власності, його найманих працівників та інших громадян, а також інших юридичних осіб повинно вирішуватись в кожному конкретному випадку з урахуванням, зокрема, таких обставин: яка шкода заподіяна конкретним законним інтересам; яка шкода могла би бути заподіяна іншим конкретним законним інтересам, на користь яких вчинені дії службовою особою, або у разі їх невчинення; яка шкода могла би бути заподіяна конкретним законним інтересам, зокрема, інтересам підприємства, установи, організації, у разі невчинення службовою особою тих дій, які вона вчинила в законних інтересах підприємства, установи чи організації за рахунок невчинення інших дій в інтересах держави, суспільства, інших юридичних чи фізичних осіб, чи навпаки [12; 13, с. 44].

Так, М.І. Хавронюк писав, що ст. 364 КК є дуже складною в застосуванні, оскільки містить багато оціночних ознак і застосовується лише як додаткова, а тому потреби в ній немає. Ї̈і відсутність в КК цілком може компенсуватися кваліфікуючою ознакою на кшталт «вчинення злочину службовою особою з використанням службового становища [14, с. 64]. Згодом правник уточнив свою позицію, вказавши на допустимість кримінальної відповідальності за умисне зловживання службовим становищем у формі порушення законодавства службовою особою під час виконання своїх функцій з метою одержання неправомірної вигоди для себе чи іншої особи; в решті випадків «вчинення діяння службовою особою з використанням службового становища» має передбачатись як обтяжуюча ознака у статтях КК про діяння, що вчиняються службовими особами [15, с. 11]. Надалі, піддаючи критиці передбачений ст. 364 КК склад злочину, М.І. Хавронюк зазначає, що в більшості кримінальних кодексів держав Свропи, крім держав СНД, не передбачено відповідальності за зловживання владою чи службовим становищем та за перевищення влади чи службових повноважень.

Суб'єкт злочину - спеціальний, тобто службова особа, якою може бути і працівник Національної поліції. Суб'єктивна сторона характеризується щодо діяння - прямим умислом та спеціальною метою - одержання будь-якої неправомірної вигоди для самої себе чи іншої фізичної або юридичної особи, а щодо наслідків, передбачених ч. 1 або ч. 2 ст. 364 КК України, - умислом або необережністю [5, с. 846].

У злочині, передбаченому ст. 364 КК України, мета являє собою уявлення суб'єкта про той бажаний результат - одержання будь-якої неправомірної вигоди для самої себе чи іншої фізичної або юридичної особи, якого він прагне досягти як шляхом її погодженого переходу, так і без нього, що визначає спрямованість діяння. 
Загальною ознакою будь-якого зловживання владою або службовим становищем, зловживання повноваженнями службовою особою $є$ спосіб вчинення злочину - використання наданих повноважень, свого становища, що утворює собою виконавчий зміст злочинів у сфері службової діяльності. Цей спосіб вчинення злочинів за своєю суттю полягає не в простому невиконанні покладеного обов'язку, а в застосуванні наданих повноважень проти покладеного обов'язку, всупереч інтересам служби та становить фактично зраду обов'язку. Під використанням влади чи службового становища обгрунтовано, на нашу думку, розуміється вчинення як дій, що безпосередньо входять до кола службових повноважень службової особи, зумовлених покладеними на неї обов'язками з виконання відповідних функцій, так і дій, зумовлених її службовим авторитетом, іï зв'язками з іншими службовими особами, можливістю здійснити вплив, зумовлений іï службовим становищем, на інших службових осіб [16, с. 126].

Притягнення до кримінальної відповідальності і за зловживання владою, пов'язане з установленням безпосереднього зв'язку між службовим становищем, компетенцією службової особи, змістом і обсягом наданих повноважень та їх використанням для вчинення злочину. В будь-якому разі службова особа усвідомлює, що використовує службове становище всупереч інтересам служби, хоча у разі перевищення влади вона усвідомлює явний вихід за межі наданих повноважень, що і визначає специфіку цього злочину, та виокремлення законодавцем деяких спеціальних видів перевищення влади або службового становища зі складу зловживання владою або службовим становищем.

Таким чином, злочини у сфері службової діяльності, що вчиняються працівниками патрульної поліції, - це суспільно небезпечні протиправні діяння, передбачені розділом XVII Ocoбливої частини закону про кримінальну відповідальність, що посягають на нормальну діяльність правоохоронних органів та вчиняються громадянами України, які склали Присягу поліцейського, проходять службу на відповідних посадах у патрульній поліції і яким присвоєно спеціальне звання поліції під час виконання ними службових обов'язків. Зазначені суспільно небезпечні діяння поділяються на ті, що пов'язані із загальнопрофесійними аспектами діяльності (ст. 364, 365,367 КК України), ті, що пов'язані із набуттям або укриттям незаконної матеріальної вигоди (366-1, 368, 369, 369-2 КК України); та ті, що пов'язані із спеціальною діяльністю (ст. 366, 370 КК України). Залежно від категорії посади (служби, підрозділу) змінюється специфіка виконуваних службових функцій, а отже, і зміст службових повноважень та компетенції, якими працівники володіють відповідно до службового становища. Водночас використання службових повноважень і можливостей, що передбачені службовим становищем, крім того, буде зумовлювати не тільки різний характер злочину, але і тяжкість наслідків.

Системоутворюючою властивістю, що поєднує корисливий мотив і злочинне його досягнення, виступає інваріантна кримінальна діяльність працівників патрульної поліції у своєму розвитку, де корисливий мотив визначає характер, зміст і природу, а корупційна форма його реалізації конкретизує спрямованість цієї специфічної злочинної діяльності. Таким чином, злочини у сфері службової діяльності, що вчиняють працівники патрульної поліції, можна визначити як антисоціальне явище й відносно масове суспільно-небезпечне збагачення, що проявляється у вчиненні злочинів у сфері службової діяльності.

Висновки. Як висновок зазначимо, що на шляху реалізації проголошеного в Україні стратегічного курсу на європейську інтеграцію, упровадження задекларованих у нормах національного й міжнародного права гарантій охорони прав і свобод людини та громадянина пріоритетними є оптимізація засад функціонування органів і підрозділів Національної поліції, удосконалення правового статусу поліцейських. Важливу роль у цьому відіграють заходи, спрямовані на запобігання вчиненню поліцейськими кримінальних правопорушень. Злочини у сфері службової діяльності, що вчиняються працівниками патрульної поліції, є сегментом корупційних правопорушень, учинених працівниками правоохоронних органів. Серед чинників, що сприяють поширенню таких діянь у поліції та їх латентності, головними варто визнати недостатньо чітку регламентацію службових повноважень груп кадрів і категорій персоналу, приховування слідів як самими правопорушниками, так і їх безпосередніми керівниками, а також зв'язок службових зловживань 3 іншими категоріями правопорушень, до яких можуть бути причетні потерпілі та інші зацікавлені особи. Забезпечення належного стану дисципліни та законності серед особового складу поліції грунтується на стратегії випередження, що полягає у проведенні комплексу заходів, спрямованих на виявлення, запобігання й припинення корупційних, злочинних та інших протиправних діянь у поліцейських колективах. 


\section{Список використаних джерел:}

1. Про зареєстровані кримінальні правопорушення та результати їх досудового розслідування. Генеральна прокуратура України. URL: http://www.gp.gov.ua/ua/stat.html.

2. Довідка про злочини, учинені в Україні за 2013-2018 рр.: службовий документ / Департамент аналітичної роботи та організації управління МВС України. Київ, 2019. 124 с.

3. Аналітична довідка про основні тенденції розвитку безпекової ситуації в Україні та стан виконання пріоритетних завдань центральними органами виконавчої влади, діяльність яких спрямовується і координується Міністром, за 2018 рік. Київ : ДНДІ МВС України, 2018. 95 с.

4. Дудоров О.О. Вибрані праці 3 кримінального права. Луганськ : РВВ ЛДУВС ім. Е. О. Дідоренка, 2010. С. 849-852.

5. Науково-практичний коментар Кримінального кодексу України / Д.С. Азаров, В.К. Грищук, А.В. Савченко [та ін.]; за заг. ред. О.М. Джужі, А.В. Савченка, В.В. Чернєя. Київ : Юрінком Інтер, 2016. 1064 c.

6. Кримінальний кодекс України: Закон від 5 квіт. 2001 р. № 2341-III. Верховна Рада України. URL: http://zakon4.rada.gov.ua/laws/show/2341-14.

7. Боднар В.С. Кримінально-правовий аналіз злочинів у сфері службової діяльності, що вчиняються працівниками ОВС. Актуальні проблеми розслідування злочинів: зб. тез доп. III Всеукр. наук.-практ. конф. (Київ, 1 лип. 2014 р.). Київ : Нац. акад. внутр. справ, 2014. С. 225-228.

8. Мартиненко О., Ігнатов О. Феномен правопорушень серед працівників міліції: питання кримінально-правової дефініції. Право Украӥни. 2005. № 1. С. 60-63.

9. Ігнатов О. Мотивація насильницьких злочинів, що вчиняються працівниками органів внутрішніх справ. Право Украӥни. 2008. № 4. С. 97-100.

10. Ігнатов О.М. Класифікація злочинів, що вчиняються працівниками органів внутрішніх справ. Ученые записки Таврического начионального университета им. В. И. Вернадского. 2008. T. 21 (60). № 2. C. 211-217.

11. Злочини проти правосуддя: навч. посіб. / за заг. ред. проф. В. І. Борисова, проф. В.І. Тютюгіна. Харків : Нац. ун-т «Юридична академія України ім. Ярослава Мудрого», 2011. 160 с.

12. Про державну службу: Закон від 10 груд. 2015 р. Верховна Рада Украйни. URL: http://zakon5.rada.gov.ua/laws/show/889-19.

13. Хашев В.Г. Кримінальна відповідальність за зловживання владою або службовим становищем : дис. ...канд. юрид. Наук : 12.00.08. Дніпропетровськ, 2007. 259 с.

14. Хавронюк М.І. Довідник з Особливої частини Кримінального Кодексу України. Київ, 2004. $504 \mathrm{c}$.

15. Хавронюк М. «Проблема Т.» і законні засоби ії вирішення. Дзеркало тижня. 2012. 24 берез. № 11. С. 11.

16. Мартиненко В.О. Особливості кримінальної відповідальності за зловживання владою або службовим становищем, що вчиняють державні службовці. Науковий вісник Національної академії внутрішніх справ. 2017. № 3(104). С. 118-132. 